\title{
Suitability Evaluation of CCME-WQI and GWQI for the Modeling of Groundwater and Human Health Risk Assessment of Heavy Metals - Eastern India
}

\section{Shivam Saw}

IIT (ISM): Indian Institute of Technology

Jaydev Kumar Mahato

IIT (ISM): Indian Institute of Technology

Prasoon Kumar Singh ( $\sim$ pks0506@iitism.ac.in )

IIT (ISM): Indian Institute of Technology

\section{Research Article}

Keywords: Groundwater, Heavy metals, Spatial distribution, CCMEWQI, GWQI, Health Risk

Posted Date: October 22nd, 2021

DOI: https://doi.org/10.21203/rs.3.rs-1000020/v1

License: (c) (i) This work is licensed under a Creative Commons Attribution 4.0 International License.

Read Full License 

6 7

\title{
Suitability evaluation of CCME-WQI and GWQI for the modeling of groundwater and human health risk assessment of heavy metals - Eastern India
}

Shivam Saw ${ }^{1}$, Jaydev Kumar Mahato ${ }^{1}$, Prasoon Kumar Singh ${ }^{1 *}$

Department of Environmental Science \& Engineering, Indian Institute of Technology (ISM), Dhanbad-826004, India.

*Email: pks0506@iitism.ac.in

\begin{abstract}
The present study assessed the suitability of groundwater by using the Canadian Council of Ministers of the Environment Water Quality Index (CCME-WQI) and the Groundwater Water Quality Index (GWQI) Model. Six heavy metals viz. arsenic (As), Iron $(\mathrm{Fe})$, Manganese $(\mathrm{Mn})$, Copper $(\mathrm{Cu})$, Lead $(\mathrm{Pb})$, and Nickel $(\mathrm{Ni})$ were investigated in the groundwater from 65 locations of Ranchi city by the Inductively Coupled Plasma-Mass Spectrometry (ICP-MS). The spatial distribution of WQI was established by Inverse Distance Weighted (IDW) interpolation technique using ArcGIS 10.3. The mystery of hydrogeochemical evolution in groundwater was elucidated by plotting the Piper trilinear diagram of major cations $\left(\mathrm{Ca}^{2+}, \mathrm{Na}^{+}, \mathrm{Mg}^{2+}, \mathrm{K}^{+}\right)$and anions $\left(\mathrm{HCO}_{3}{ }^{-}, \mathrm{Cl}^{-}, \mathrm{SO}_{4}{ }^{2-}, \mathrm{F}^{-}\right)$. Significant fluctuations in the water level during PRM (7.38mbgl to $10.5 \mathrm{mbgl}$ ) and POM (4.3$6.4 \mathrm{mbgl}$ ) season were observed in the central part of the study area. Performance evaluation of WQI models indicated that the CCMEWQI performed better than GWQI for assessing the quality index of groundwater with a comparatively higher coefficient value $\left(\mathrm{R}^{2}\right.$ 0.97) and less NMSE (4.34) RMSE (27.38), MAPE (0.357). The health risk of heavy metals via the oral route was investigated by calculating hazard quotient (HQ) and hazard index (HI). The HI value was observed maximum for As followed by $\mathrm{Mn}>\mathrm{Pb}>\mathrm{Ni}>\mathrm{Fe}>\mathrm{Cu}$ for adults and children. The spatial distribution map of $\mathrm{HI}$ indicated that most of the studies area are at a non-carcinogenic risk of heavy metals. The study provides immense help for water authorities and public health decision-makers to prevent the community's health risk.
\end{abstract}

Keywords: Groundwater; Heavy metals; Spatial distribution; CCMEWQI; GWQI; Health Risk 8 9 0 1 2 


\subsection{Introduction}

34 Globally, groundwater is deliberated as the safest reservoir and a good source of essential elements for life preservatives. It is unevenly distributed below the earth's surface, mainly dependent upon geographical location, the permeability of rocks, rainfall, and infiltration rate, etc. (Egbueri 2020; Bhutiani et al. 2016; Mazhar and Ahmad 2020). Approx. $33 \%$ of the global populace relies on groundwater for drinking purposes (Nickson et al. 2005; Mahato and Gupta 2021). According to World Bank 2010, about $85 \%$ of domestic requirements in India are satisfied by groundwater only; however, it has minimal availability of these resources (World Bank 2010). The Indian state like Jharkhand, West Bengal, Orissa, Uttar Pradesh, Andhra Pradesh, Rajasthan, and Punjab was found to be at risk of acute groundwater depletion (Tiwari and Singh 2014). Despite being more protected than surface water, groundwater is highly susceptible to contamination with various pollutants. (Khalid et al. 2020; Bhutiani et al. 2016). The quality of groundwater is being deteriorated for several reasons, like increasing population, activities like agriculture, industrialization and disposal wastage, etc. (Wagh et al. 2016; Panaskar et al. 2016). Hence, it is crucial to evaluate the suitability of water onsite to ensure public safety. The water quality index (WQI) is a widely accepted mathematical tool for classifying drinking water based on various water quality parameters. Initially, the WQI model was proposed by Horton (1965), and later in the year 1970, the National Sanitation Foundation (NSF) had standardized this method for its general application as NSFWQI (Brown et al. 1970). However, the various water quality indices were already reviewed globally till 1970 (Steinhart et al. 1981). Afterward, in 1995, the Canadian Council of Ministers of the Environment (CCME) has developed another WQI (CCME-WQI) model based on the British Columbia Water quality Index (BCWQI) to assess and simplify the water quality data (Rocchini and Swain 1995; CCME 2001).

The Indian interest in WQI was received in 1983 when Bhargava (1983) used this tool to classify and zone the river Ganga. Later by the year, many research was carried out based on WQI to evaluate the suitability of groundwater (GWQI) in various parts of the country, viz. Nagpur, Maharashtra (Rajankar et al. 2009), Tumkur, Karnataka (Ramakrishnaiah et al. 2009), Visakhapatnam, Andhra (Latha and Rao 2010), Virudunagar, Tamil Nadu (Magesh et al. 2013), Rajkot, Gujarat (Gopal et al. 2016), Nashik Maharashtra (Wagh et al. 2017), Telangana (Adimalla 2019), Ramgarh and Hazaribagh, Jharkhand (Kumar and Krishna 2021), Varanasi, Uttar Pradesh (Chaurasia 2021), etc. However, there is minimal information available on the application of CCME-WQI to assess the quality of groundwater (Venkatramanan et al. 2016; Wagh et al. 2017). In addition, it was also noted that no work had been carried out to compare the effectiveness of GWQI and CCME-WQI model to evaluate the suitability of groundwater for public consumption.

Hence the present study was undertaken with the objective of (i) physicochemical characterization, including correlation analysis, ion balancing, and piper diagram with special reference to the groundwater of Ranchi city (ii) the effect 62 of seasonal variation on water level fluctuation (iii) Spatial distribution of WQI with the help of Inverse Distance Weighted (IDW) interpolation of GIS and, (iv) the comparative assessment of GWQI and CCME-WQI model to evaluate the suitability of groundwater for drinking purpose. The study provides immense utility to the groundwater board, industries, and researchers for adopting the best WOI model to ensure public safety. 


\subsection{Materials and methods}

\subsection{The study area and sampling}

71 For the study, the groundwater sample was collected from various 65 locations of the Ranchi district $\left(23^{0} 15^{\prime} \mathrm{N}\right.$ to $23^{0} 25^{\prime} \mathrm{N}$ 72 latitude $85^{\circ} 15^{\prime} \mathrm{N}$ to $85^{\circ} 25^{\prime} \mathrm{E}$ longitude), which lay in the survey of India toposheet no $73 \mathrm{E} / 7$ (Fig. 1). It is the capital city of 73 Jharkhand, located in the southern part of the Chotanagpur, and falls under the western part of the Deccan plateau (GSI 2001).

74 All the water samples were taken in triplicate during the pre-monsoon (PRM) and post-monsoon (POM) season of the year 75 2018-19.

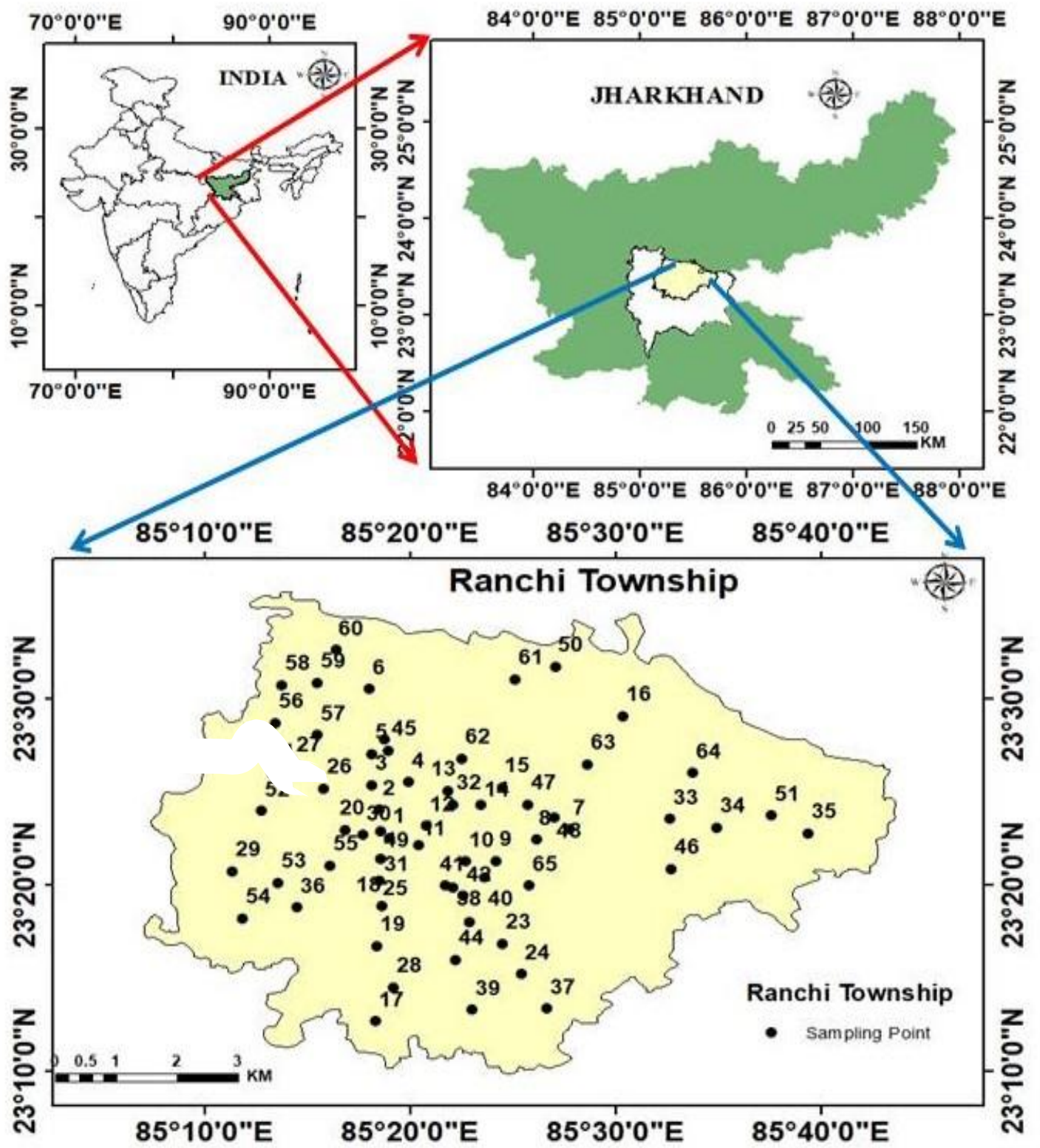

Fig. 1 Sampling point Location map of the study area 


\subsection{Analytical method}

The physicochemical analysis of the collected sample was carried out as per the standard methods for examining water and wastewater APHA (2012) in the Department of Environmental Science \& Engineering IIT (ISM) Dhanbad laboratory. For the analysis of major cations ( $\mathrm{Ca}, \mathrm{Mg}, \mathrm{K}$ and $\mathrm{Na}$ ) and anions $\left(\mathrm{Cl}, \mathrm{HCO}_{3}, \mathrm{SO}_{4}\right.$, and $\mathrm{NO}_{3}$ ) Flame Photometer (ESICO 1385) was used. Whereas the monitoring of nitrate $\left(\mathrm{NO}_{3}{ }^{-}\right)$and sulfate $\left(\mathrm{SO}_{4}{ }^{2-}\right)$ were carried out using the UV-Vis spectrophotometer (Motras Scientific, India). The heavy metal concentration was monitored using ICP-MS (Perkin Elmer model ELAN DRCe, 710 Bridgeport Avenue Shelton, Connecticut 06484-4794, United States). The ion-balance chemistry of groundwater was evaluated by AQUA CHEM (version 1.1.5.1.) software. The spatial distribution of WQI was established by the IDW interpolation technique using ArcGIS 10.3. An electronic water level indicator (Model-K-11107) was used to monitor the level of water.

\subsection{WQI modeling approach}

For this study, two WQI models viz. GWQI and CCME-WQI were applied to categories the groundwater quality for drinking

purposes. The CCME-WQI model was initially conceptualized by the Canadian Water Quality Index (CWQI), having certain theoretical advantages over the conventional WQI. A total of 12 physicochemical parameters (pH, EC, TDS, TH, Calcium, Magnesium, Sodium, Potassium, Chlorides, Fluorides, Sulfates, and Nitrate) were considered for the estimation of suitability groundwater from BIS (2012).

The computation of CCME-WQI involves three general steps viz. (i) choosing variables, (ii) selecting guidelines, and (iii) calculation of index scores. Further, the model was divided into three factors [Factor 1 (Scope), Factor 2 (Frequency), and Factor 3 (Amplitude)] to produce a single unit less value that indicates the overall quality of water.

Factor 1 (Scope) assess the proportion through which the variables deviate from their objectives and can be expressed as (Eq. 1)

$$
\mathrm{F} 1=\left(\frac{\text { Number of failed variables }}{\text { Total number of variables }}\right) * 100
$$

Factor 2 (Frequency) represent the percentage of failed tests, and can be expressed as (Eq. 2)

$$
F 2=\left[\frac{\text { Number of failed tests }}{\text { Total number of tests }}\right] * 100
$$

The Factor 3 (amplitude) represents the amount through which the value of failed test deviate from their objectives, and can be calculated by following the simple three steps as below:

(a) Computation of excursion that represents the number of an individual concentration is more significant than or less than the 107 objective, and can be expressed as (Eq 3, 4):

108 Case I: When the test value must not exceed the objective

$$
\text { execursion }_{i}=\left[\frac{\text { Fail test value }}{\text { objective } j}\right]-1
$$


Case II: When the test value must not fall below the objective

$$
\text { execursion }_{i}=\left[\frac{\text { objectivejue } j}{\text { Failed test vale }}\right]-1
$$

(b) Computation of normalized sum of excursion (NSE) that represent the collective amount through which the individual

113 tests are out of compliance, is calculated as (Eq 5):

$$
n s e=\left[\frac{\sum_{i=0}^{n} \text { excursion } i}{\text { no. of tests }}\right]
$$

(c) Computation of Factor 3 (amplitude) with the help of an asymptotic function that scales the normalized sum of the excursions from objectives (nse) within $0 \sim 100$ (Eq. 6).

$$
F 3=\left[\frac{n s e}{0.01 n s e+0.01}\right]
$$

The CCME-WQI is calculated as (Eq. 7):

$$
\text { CCMEWQI }=100-\frac{\sqrt{F_{1}^{2}+F_{2}^{2}+F_{3}^{2}}}{\pi}
$$

The constant divisor (1.732) normalizes the resultant values in the ranges from 0 to 100.0 represents the worst and 100 represents the best quality of water quality, and the value between 0 to 100 was categorized into marginal, fair, and good.

The standards for drinking water recommended by the Bureau of Indian Standard (BIS 2012) was used for the computation of GWQI, involving three steps:

In the very first step, each of the 12 variables assigned a weight $\left(w_{i}\right)$ according to their relative importance (ranging from 1 to 5) in the overall quality of water for drinking purposes.

In the second step, the relative weight $\left(\mathrm{W}_{\mathrm{i}}\right)$ is computed by using Eq.:

$$
\mathrm{W}_{\mathrm{i}}=\frac{w_{i}}{\sum_{i=1} w_{i}}
$$

Where $\mathrm{W}_{\mathrm{i}}$ and $w_{i}$ represent the relative weight and weight of each parameter, respectively, and $\mathrm{n}$ is the number of parameters. each sample of water with its respective standard according to the guidelines of BIS and then is multiplied by 100 (Eq 9):

$$
\mathrm{qi}=(\mathrm{Ci} / \mathrm{Si})^{*} 100
$$

Where $q i$ and $C i$ are the quality rating and concentration of each chemical parameter in each water sample in $\mathrm{mg} / \mathrm{L}$, respectively, $S i$ is taken from the guideline of BIS (2012).

Hence, for computing the GWQI, $S I_{i}$ index of each parameter is calculated initially (Eq. 10), which is then used to determine the WQI by Eq. 11.

$$
\begin{aligned}
& \mathrm{SI}_{\mathrm{i}}=\mathrm{Wi} * \mathrm{qi} \\
& \mathrm{WQI}=\sum \mathrm{SI}_{\mathrm{i}}
\end{aligned}
$$


Where $S I_{i}$ the is the sub-index of $i^{\text {th }}$ parameter, $q_{i}$ is the rating based on the concentration of the $i t h$ parameter, and $n$ is the number of parameters.

The spatial distribution map of GWQI and CCMEWQI models was plotted using the interpolation technique (IDW) for PRM and POM season.

\subsection{Performance evaluation of WQI models}

The performance evaluation of WQI models was carried out using various statistical metrics viz. Normalized Mean Square Error (NMSE), Root Means Square Error (RMSE), Means Absolute Percentage Error (MAPE) and $\mathrm{R}^{2}$. The equation for the determination of NMSE, RMSE and MAPE is mentioned in Eqs. (12), (13) and (14) respectively.

$$
\begin{aligned}
\text { NMSE } & =\frac{(n-1) \sum_{5=1}^{n}\left[\left(x_{m}\right)_{i}-\left(x_{s}\right)_{i}\right]^{2}}{(n) \sum_{i=1}^{n}\left[\left(x_{m}\right)_{i}-\left(\vec{x}_{m}\right)_{i}\right]^{2}} \\
\text { RMSE } & =\sqrt{\frac{1}{n} \sum_{i=1}^{n}\left[\left(x_{m}\right)_{i}-\left(x_{s}\right)_{i}\right]^{2}} \\
\text { MAPE } & =\frac{1}{n} \sum_{i=1}^{n} \frac{\left|\left(x_{s}\right)_{i}-\left(x_{m}\right)_{i}\right|}{\left(x_{m}\right) i}
\end{aligned}
$$

Where $x_{m}, x_{s}$ and $\vec{x}_{m}$ are the measured value, standard values and average measured value respectively, and $\mathrm{n}$ is the number of samples.

\subsection{Health Risk Analysis}

The non-carcinogenic health risk of heavy metals in groundwater through oral ingestion was determined by calculating hazard index (HI) based on USEPA (1989) (Eq.15).

$$
\mathrm{ADD}=(\mathrm{Cw} \times \mathrm{IR} \times \mathrm{EF} \times \mathrm{ED}) /(\mathrm{BW} \times \mathrm{AT})
$$

Where, ADD stands for heavy metals average daily dose ( $\mathrm{mg} / \mathrm{kg} /$ day), $\mathrm{Cw}$ is heavy meatls concentration in water, ( $\mathrm{mg} / \mathrm{l}), \mathrm{IR}$ is the ingestion rate (3 1/day for adults) (Bhutiani et al. 2016), EF is the exposure frequency (days/year), ED is the exposure duration (years), BW is the body weight (57.5 kg adults) (ICMR 2009) and AT is the averaging time (days).

The characterization of risk was quantified by potential non-carcinogenic risks as hazard quotient (HQ). It is the ratio of exposure level of individual elements to the reference dose (RfD) of the same (Wagh et al. 2018; Bhutiani et al. 2016). (Eq. 16).

$$
\mathrm{HQ}=\text { exposure level (ADD) / RfD }
$$

The RfD values for all the elements were based on USEPA (2011).

The HI is usually a multiple substance/ single-exposure pathway ratio and can be express as sum of all metal's HQ (Eq.17) (Wagh et al. 2018).

$$
H I=\sum H Q
$$


172 Suitable quality affirmation methodology and safeguard were carried out to ensure reliability, and samples were carefully handled to avoid contamination. Glassware was appropriately cleaned, and analytical grade reagents were used. Milli Q water was utilized throughout the analysis. Reagent blank determinations were used to correct the instrument readings. The analysis accuracy was checked by analyzing the reference standard of water (NIST 1640a and NIST 1643b). The precision obtained in most cases was better than 5\% RSD with comparable accuracy.

\subsection{Results and Discussion}

\subsection{Water quality characterization, correlation analysis, and hydrogeochemical Investigation}

The descriptive statistics of physicochemical quality of groundwater for PRM and POM season are listed in the (Table 1). All the parameters are well within the prescribed guideline value of the Bureau of Indian Standards (BIS 2012), and showed good quality of water for drinking purpose, except total hardness, nitrate and fluoride. The range value of total hardness (165 - 603.8 $\mathrm{mg} / \mathrm{L}$ ) was found slightly higher in PRM season than the permissible limit of BIS (600 mg/L), however it considered to be safe for human consumption. In addition, the concentration range of nitrate and fluoride were also above the BIS permissible vale (Table 1). The use of excessive of fertilizer in agricultural activity and the existence of fluoride rocks like charnockite and granulite, may be one of the major reason for the occurrence of high level of these contaminentents in to the ground water, respectively of this area (Srinivasamoorthy et al. 2007; Panaskar et al. 2016; Rao et al. 2013).

In order to investigate the correlation of major cation $\left(\mathrm{Ca}^{2+}, \mathrm{Na}^{+}, \mathrm{Mg}^{2+}, \mathrm{K}^{+}\right)$and anions $\left(\mathrm{HCO}_{3}{ }^{-}, \mathrm{Cl}^{-}, \mathrm{SO}_{4}{ }^{2-}, \mathrm{F}^{-}\right)$with other water quality parameters the Pearson correlation matrix was established for both the season (Table. 2a-b). While concerning the ions, organic and inorganic substances of water TDS is flagship, as it represent the sum of all cations and anions (Tiwari and Singh 2014). The strong and significant correlation of TDS with ions suggested that the quality of the groundwater can greatly be affected by increasing the concentration of TDS ( $\mathrm{Li}$ et al. 2013). Furthermore, the positive correlation of TDS with total hardness, and alkalinity also signify that the level of bicarbonate, carbonate, calcium, magnesium, sodium and fluoride is highly depends upon the this key parameters (Mamatha and Rao, 2010; Rafique et al. 2008). The results of present study is very much similar to the findings of Raghunath (1982); Gopinath and Seralathan (2006). The Pearson correlation matrix of POM was found to exhibit similar trends as PRM (Table. 2a-b).

The mystery of hydro geochemical evolution in groundwater can be elucidated by plotting the Piper trilinear diagram of major cations and anions. In the study area, diamond-shaped Piper showed that the majority of ground water samples are encompasses with $\mathrm{Mg}-\mathrm{HCO}_{3}$ and $\mathrm{Ca}_{-} \mathrm{Cl}^{-}$in PRM and $\mathrm{POM}$ season, respectively. The left triangle indicating the existence of cation, whereas the right for anions (Fig. 2a-b). In addition, it was also noted that the cation $-\mathrm{Ca}^{2+}$ was found to be dominated in both the season. Whereas in the case of anions -bicarbonate and chloride showed their ascendancy in PRM and POM, respectively. The deviation in the occurrence level of these cations and anions may be due to the fact that geological condition, natural rocks, contamination of groundwater with domestic and industrial effluents, use of fertilizers, septic tanks etc. (Negrel and Roy 1998; Raghunath 1982; Gopinath and Seralathan 2006) . 
Table 1 Statistical Analysis of Physico chemical parameter of Groundwater Sample

\begin{tabular}{|c|c|c|c|c|c|}
\hline & \multicolumn{2}{|c|}{$\begin{array}{c}\text { PRM } \\
(\mathrm{n}=65)\end{array}$} & \multicolumn{2}{|c|}{$\begin{array}{c}\text { POM } \\
(\mathrm{n}=65)\end{array}$} & \multirow{2}{*}{$\begin{array}{l}\text { Desirable- } \\
\text { permissible } \\
\text { (BIS 2012) }\end{array}$} \\
\hline & Range & Mean \pm SD & Range & Mean \pm SD & \\
\hline $\mathrm{pH}$ & $6.6-7.7$ & $7.2 \pm 0.27$ & $6.5-8.1$ & $7.16 \pm 0.29$ & $6.5-8.5$ \\
\hline $\mathrm{EC}(\mathrm{us} / \mathrm{cm})$ & $256-1054$ & $696.48 \pm 183$ & $177-884$ & $553.87 \pm 205.62$ & ---- \\
\hline TDS & $234.6-925$ & $477.01 \pm 108$ & $163-774$ & $474.55 \pm 168$ & $500-2000$ \\
\hline$\left(\mathrm{Ca}^{2+}\right)$ & $36.32-147$ & $89.31 \pm 26.48$ & $18.6-141$ & $71.41 \pm 30.97$ & $75-200$ \\
\hline$(\mathrm{Mg} 2+)$ & $5.79-77$ & $31.44 \pm 14.45$ & $6.95-60.5$ & $26.66 \pm 11.66$ & $30-100$ \\
\hline Sodium & $5.87-90.23$ & $41.91 \pm 15.67$ & $3.21-68.1$ & $33.84 \pm 14.45$ & 200 \\
\hline Potassium & $2.13-18$ & $9.59 \pm 3.64$ & $1.35-15.62$ & $7.16 \pm 3.96$ & 12 \\
\hline Total Alkalinity & $90.1-348$ & $202.23 \pm 62.38$ & $78.68-481$ & $212.91 \pm 106.57$ & $200-600$ \\
\hline Total Hardness & $165-603.8$ & $348.38 \pm 106.5$ & $94-501.2$ & $288.18 \pm 104.48$ & $200-600$ \\
\hline Sulfate & $26.98-151$ & $76.62 \pm 30.23$ & $9.32-121.36$ & $59.36 \pm 29.01$ & $200-400$ \\
\hline Nitrate & $0.04-56$ & $18.95 \pm 14.47$ & $0.27-48.65$ & $15.66 \pm 13.83$ & 45 \\
\hline Chloride & $31-172.4$ & $87.26 \pm 29.57$ & $20.29-162$ & $80.68 \pm 30.94$ & $250-1000$ \\
\hline $\mathrm{F}^{-}$ & $0.15-1.62$ & $0.58 \pm 0.3$ & $0.14-3.95$ & $0.63 \pm 0.53$ & $1-1.5$ \\
\hline
\end{tabular}




\begin{tabular}{|c|c|c|c|c|c|c|c|c|c|c|c|c|c|}
\hline & pH & EC & TDS & $\mathrm{Ca}^{2+}$ & $\mathbf{M g}^{2+}$ & $\mathbf{N a}^{+}$ & $\mathbf{K}^{+}$ & $\begin{array}{c}\text { Alkalinit } \\
\mathbf{y}\end{array}$ & $\mathrm{SO}_{4}{ }^{2-}$ & $\mathrm{Cl}^{-}$ & $\mathbf{F}^{-}$ & $\mathrm{NO}_{3}^{-}$ & TH \\
\hline pH & 1 & -.203 & -.241 & -.152 & -.125 & -.199 & -.121 & -.220 & $-.284^{*}$ & .095 & .068 & -.183 & -.108 \\
\hline EC & & 1 & $.655^{* *}$ & $.614^{* *}$ & $.416^{* *}$ & $.281^{*}$ & $.415^{* *}$ & $.476^{* *}$ & $.476^{* *}$ & $.287^{*}$ & .070 & .133 & $.568^{* *}$ \\
\hline TDS & & & 1 & $.799^{* * *}$ & $.694^{* * *}$ & $.305^{*}$ & $.430^{* *}$ & $.848^{* *}$ & $.764^{* * *}$ & $.358^{* * *}$ & 077 & $.358^{* * *}$ & $.871^{* * *}$ \\
\hline $\mathrm{Ca}^{2+}$ & & & & 1 & $.429^{* *}$ & .063 & $.275^{*}$ & $.571^{* *}$ & $.488^{* *}$ & $.376^{* *}$ & -.043 & $.317^{*}$ & $.826^{* *}$ \\
\hline $\mathbf{M g}^{2+}$ & & & & & 1 & .007 & $.375^{* *}$ & $.600^{* *}$ & $.597^{* *}$ & .142 & -.178 & .216 & $.829^{* *}$ \\
\hline $\mathrm{Na}^{+}$ & & & & & & 1 & -.010 & $.328^{* *}$ & .181 & .020 & -.108 & -.192 & .009 \\
\hline $\mathbf{K}^{+}$ & & & & & & & 1 & $.331^{* *}$ & $.370^{* *}$ & .215 & -.120 & .028 & $.381^{* *}$ \\
\hline Alkalinity & & & & & & & & 1 & $.664^{* *}$ & .003 & .113 & $.291^{*}$ & $.700^{* *}$ \\
\hline $\mathrm{SO}_{4}{ }^{2-}$ & & & & & & & & & 1 & -.070 & .020 & $.272^{*}$ & $.632^{* *}$ \\
\hline $\mathrm{Cl}^{-}$ & & & & & & & & & & 1 & .027 & -.117 & $.285^{*}$ \\
\hline $\mathbf{F}^{-}$ & & & & & & & & & & & 1 & .003 & -.141 \\
\hline $\mathrm{NO}_{3}^{-}$ & & & & & & & & & & & & 1 & $.355^{* *}$ \\
\hline TH & & & & & & & & & & & & & 1 \\
\hline
\end{tabular}

219

(b) POM

\begin{tabular}{|c|c|c|c|c|c|c|c|c|c|c|c|c|c|}
\hline & pH & EC & TDS & $\mathrm{Ca}^{2+}$ & $\mathbf{M g}^{2+}$ & $\mathbf{N a}^{+}$ & $\mathbf{K}^{+}$ & $\begin{array}{l}\text { Alkalinit } \\
\mathbf{y}\end{array}$ & $\mathrm{SO}_{4}{ }^{2-}$ & $\mathrm{Cl}^{-}$ & $\mathbf{F}^{-}$ & $\mathrm{NO}_{3}^{-}$ & TH \\
\hline pH & 1 & -.090 & -.050 & -.133 & -.119 & -.119 & -.128 & -.220 & -.085 & .020 & .150 & .104 & -.154 \\
\hline EC & & 1 & $.905^{* *}$ & $.609^{* *}$ & $.493^{* *}$ & $.339^{* *}$ & $.659^{* *}$ & $.570^{* *}$ & $.518^{* *}$ & $.498^{* *}$ & .163 & $.383^{* *}$ & $.677^{* *}$ \\
\hline TDS & & & 1 & $.695^{* *}$ & $.491^{* *}$ & $.470^{* *}$ & $.671^{* *}$ & $.643^{* *}$ & $.541^{* *}$ & $.547^{* *}$ & .218 & $.416^{* *}$ & $.740^{* *}$ \\
\hline $\mathrm{Ca}^{2+}$ & & & & 1 & $.352^{* *}$ & $.340^{* *}$ & $.621^{* * *}$ & $.647^{* *}$ & $.607^{* *}$ & $.637^{* *}$ & .180 & $.307^{*}$ & $.901^{* *}$ \\
\hline $\mathbf{M g}^{2+}$ & & & & & 1 & .180 & $.447^{* *}$ & $.578^{* *}$ & $.314^{*}$ & $.568^{* *}$ & .201 & $.396^{* *}$ & $.723^{* *}$ \\
\hline $\mathrm{Na}^{+}$ & & & & & & 1 & $.291^{*}$ & $.519^{* *}$ & $.349^{* *}$ & .226 & .135 & $.390^{* *}$ & $.334^{* *}$ \\
\hline $\mathbf{K}^{+}$ & & & & & & & 1 & $.627^{* *}$ & $.504^{* *}$ & $.379^{* *}$ & .155 & $.397^{* *}$ & $.664^{* *}$ \\
\hline $\begin{array}{l}\text { Alkalinit } \\
\mathbf{y}\end{array}$ & & & & & & & & 1 & $.295^{*}$ & $.337^{* *}$ & $.250^{*}$ & .218 & $.746^{* *}$ \\
\hline $\mathrm{SO}_{4}{ }^{2-}$ & & & & & & & & & 1 & $.309^{*}$ & .096 & $.338^{* *}$ & $.591^{* *}$ \\
\hline $\mathrm{Cl}^{-}$ & & & & & & & & & & 1 & .128 & $.424^{* *}$ & $.731^{* *}$ \\
\hline $\mathbf{F}^{-}$ & & & & & & & & & & & 1 & .100 & .226 \\
\hline $\mathrm{NO}_{3}^{-}$ & & & & & & & & & & & & 1 & $.408^{* *}$ \\
\hline TH & & & & & & & & & & & & & 1 \\
\hline
\end{tabular}


(a)

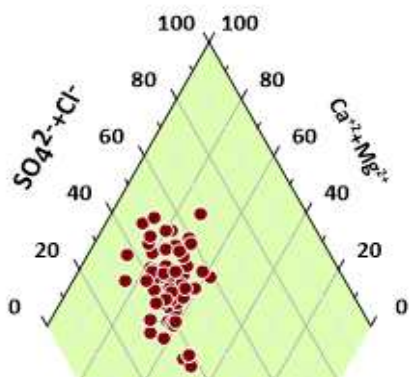

(b)
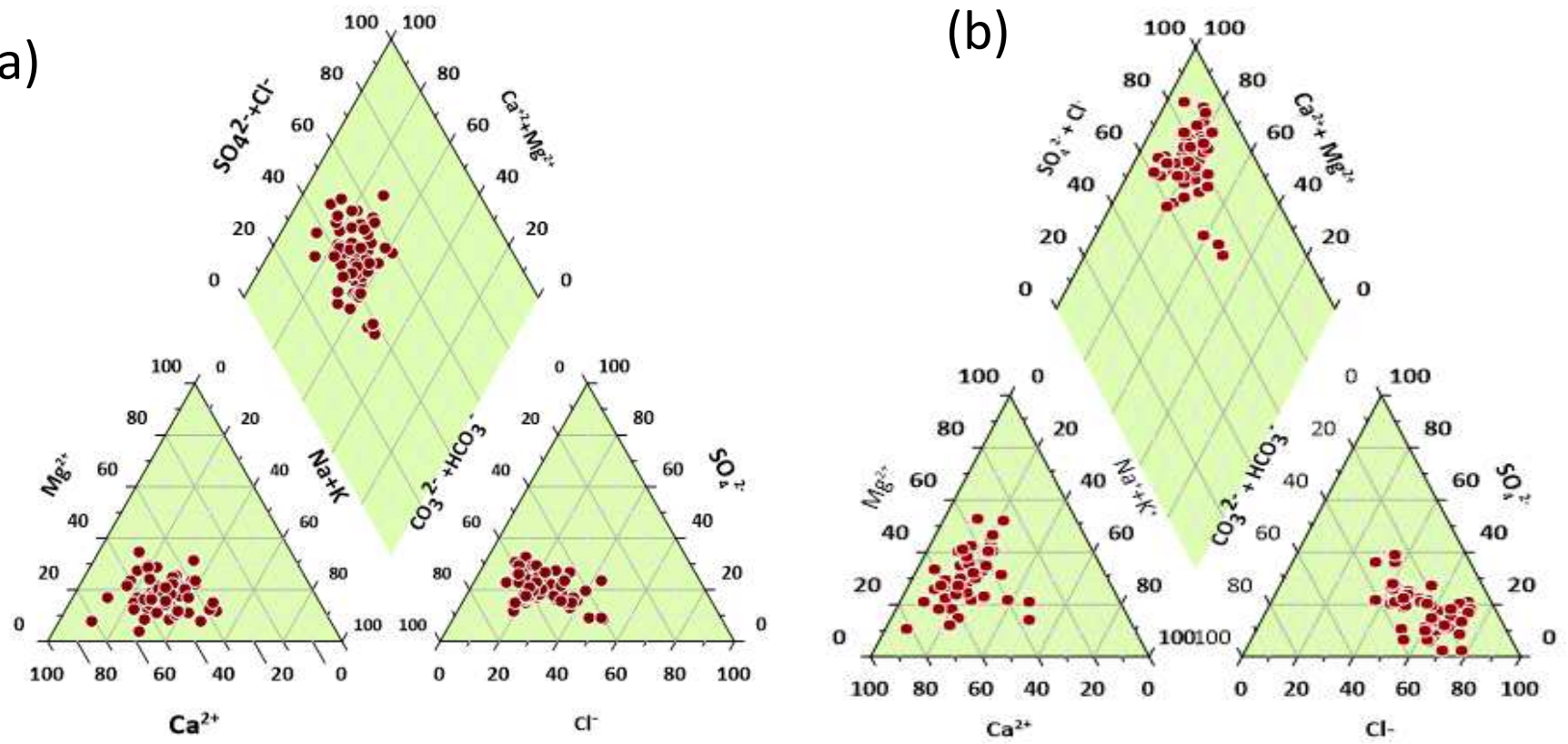

Fig. 2 Piper trilinear diagram for hydro geochemical (a) PRM (b) POM

\subsection{Seasonal Water level Fluctuation}

Being the capital city of Jharkhand, population of Ranchi is highly dense, results in over-exploitation of groundwater. Hence, the depth of water level and monitoring of seasonal fluctuation is significant for the determination of various contaminant's travels time before it reaching to ground water. The season-wise water level fluctuations in all the 65 locations of the study area were investigated using GIS based IDW interpolation technique. A great fluctuations in the water level of PRM (7.38mbgl to $10.5 \mathrm{mbgl}$ ) and POM (4.3- $6.4 \mathrm{mbgl})$ season were observed in the central part of the study area (Fig. 3a-c). This drastic variation in the seasonal water level is mainly because of recharge of rainwater into the ground in the post-monsoon season. The other factors like geological formation, permeability of rocks, infiltration rate, type of aquifers, etc. also greatly affect the level of water (Gopinath and Seralathan, 2006; Panaskar et al. 2016). In overall the western part was found to be more prone to water level fluctuations than other part of study area for all the season (Fig. 3c). The occurred reason behind this phenomenon is the rapid urbanization and over expoliation of ground water in this area. The present result is good in line with the findings of Bhutiani et al. (2016); Mazhar and Ahmad (2020). 

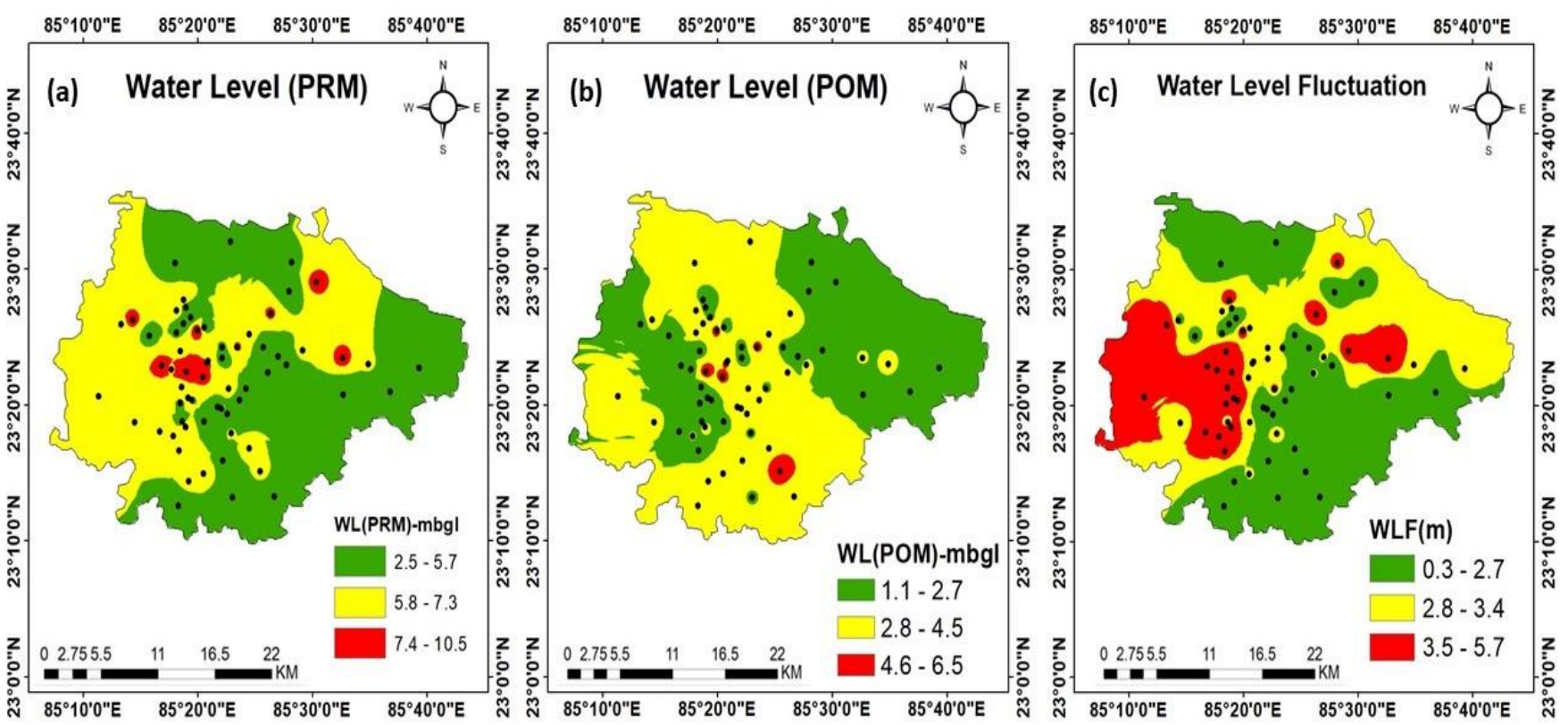

Fig. 3 Water Level (a) PRM, (b) POM and (c) Water level fluctuation

\subsection{WQI modeling approach}

The application of WQI modeling is a worthy technique for the assessment of drinking water suitability. In the present study, Fig. 4a-b explored the spatial distribution of CCMEWQI during PRM and POM season, respectively. The water class was classified into five categories, and the index value ranged from 49.5 to 96.5 (PRM) and 51.5 to 100 (POM). Considering the observation of each location during the PRM season, the class of most of the water samples falls under the fair (45\%) followed by good (31\%), marginal (17\%), and poor (2\%) categories. Tragically, the only $5 \%$ sample in this season of location no. 6,24,50 \& 55 showed excellent water quality for drinking purposes (Table. 3a). In contrast, during the POM season maximum percentage (20\%) of sample water lay in excellent class followed by good (32.3\%) and Fair (27.6\%). The results clearly indicated that the index value increase during POM compared to PRM season might be due to rainwater infiltration to the ground support in dilution (Aller et al. 1987; Ramakrishnaiah et al. 2009).

Based on GWQI modeling, the class of water was again classified into five categories, but the index value (50 to 300) of this approach was higher than CCMEWQI (Table. 3b). The spatial distribution of GWQI for PRM and POM season was depicted in Fig. 5 a-b. It was observed that the maximum percentage of water (PRM-70.7\%, POM- 75.4\%) qualified in the 'Good' category and are acceptable for drinking and other domestic activity. However, only 1.5\% sample of PRM and 20\% sample of POM season were attended for the 'Excellent' category. During this approach, it was also noticed that no water falls under the very poor and unfit categories in both seasons (Table 3b). The overall WQI of water was found comparatively upright in POM season by both the modeling approach.

The research results and sensitivity analysis revealed that CCMEWQI performed better than GWQI for assessing the quality index of groundwater. The calculated value of NMSE, RMSE and MAPE were found comparatively higher for GWQI, which supports the better applicability of CCMEWQI (Table 4). The $\mathrm{R}^{2}$ value of CMEWQI model is higher as compared to 
258 GWQI model in both the season. This model is based on the integration of all its three variables (scope $\left(F_{1}\right)$, frequency $\left(F_{2}\right)$, 259 and amplitude $\left(\mathrm{F}_{3}\right)$ into a single dimensionless score for the representation of the overall quality of water. CCMEWQI models 260 also have the advantage of flexibility in selecting tolerance and missing benchmark data (Yan et al. 2016; Mohebbi et al. 2013). 261 All these mechanisms made the CCMEWQI model performed better than GWQI.
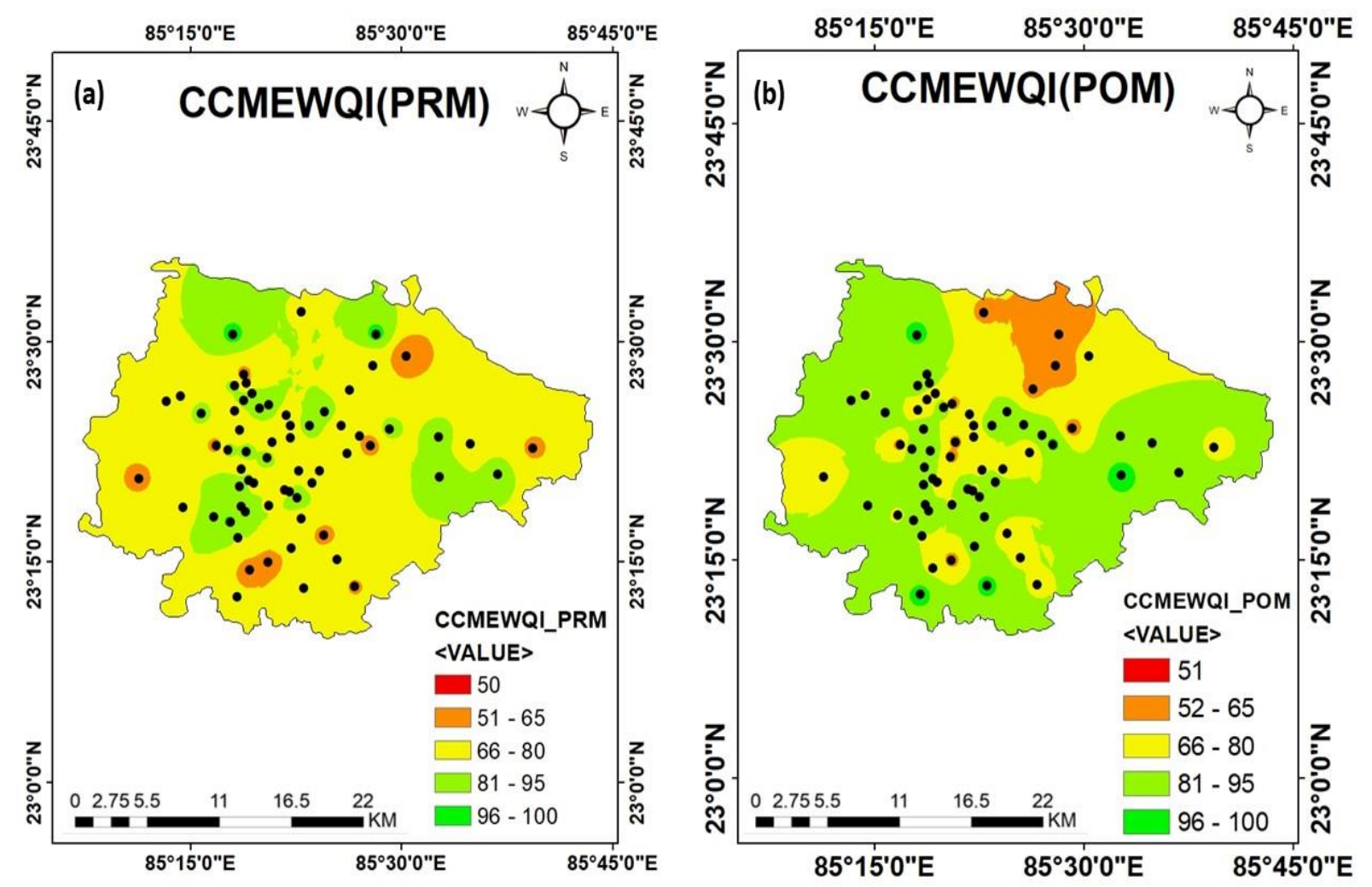

Fig. 4 Spatial distribution map of CCMEWQI (a) PRM, (b) POM 

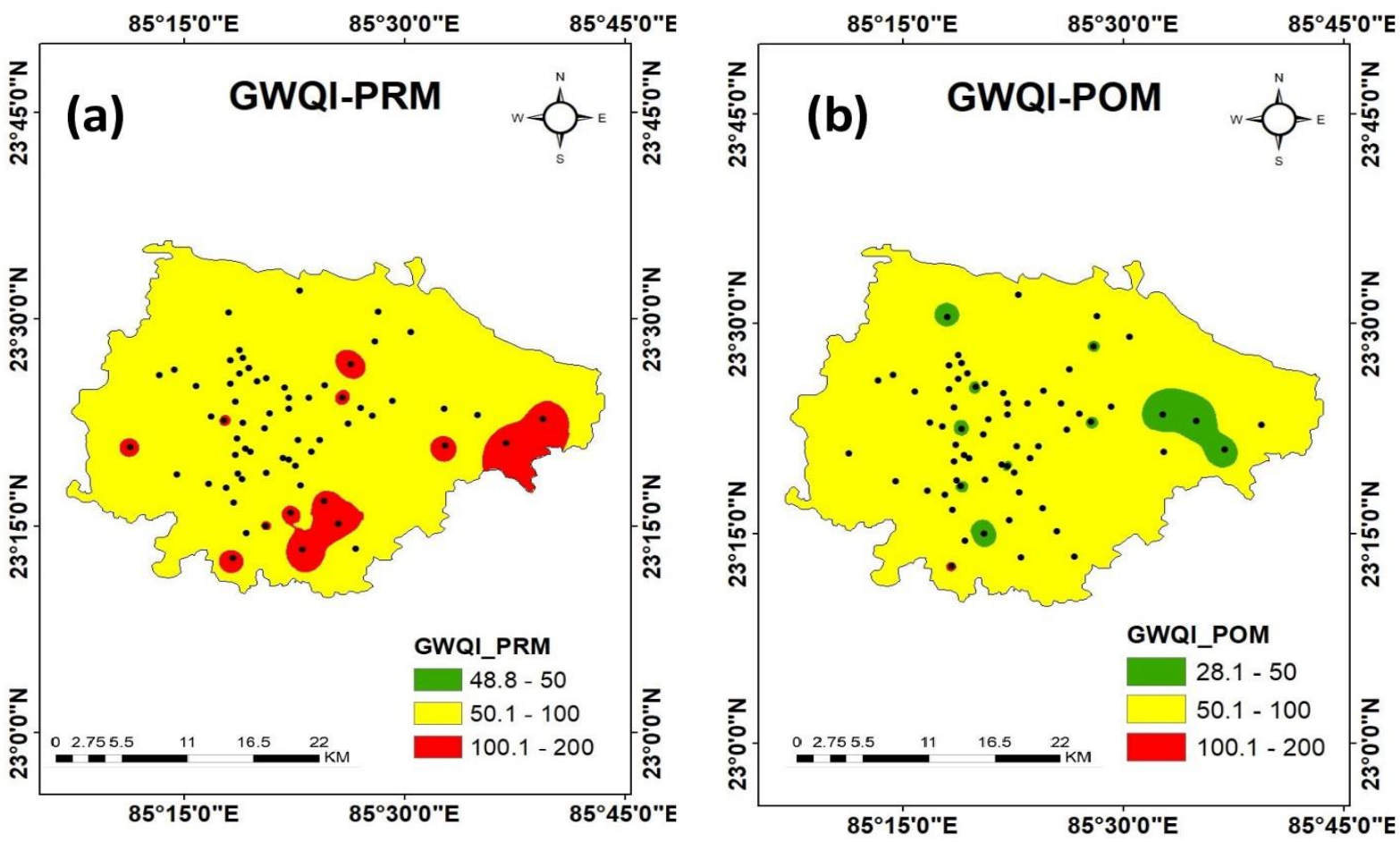

Fig. 5 Spatial distribution map of GWQI (a) PRM (b) POM

266

267 Table 3 Categorization of water quality-based (a) CCMEWQI and (b) GWQI

\begin{tabular}{|c|c|c|c|c|}
\hline \multirow{3}{*}{ Class categories } & \multicolumn{4}{|c|}{ (a) CCMEWQI } \\
\hline & \multicolumn{2}{|l|}{ PRM } & \multicolumn{2}{|l|}{ POM } \\
\hline & Sample numbers & $\begin{array}{c}\% \text { of } \\
\text { samples }\end{array}$ & Sample numbers & $\begin{array}{c}\% \text { of } \\
\text { samples }\end{array}$ \\
\hline Poor $(0-50)$ & 19 & 2 & 0 & 0 \\
\hline Marginal (51-64) & $\begin{array}{l}7,25,28,33,34,43,45,56 \\
58,59,64\end{array}$ & 17 & $3,11,12,16,17,25,46,52,54,55,59,60,63$ & 20 \\
\hline Fair (65-79) & $\begin{array}{l}2,3,8,9,10,12,13,16,20,22,26,2 \\
7,29,32,36,37,38,40,42,44,46, \\
47,48,49,52,57,60,63,65\end{array}$ & 45 & $\begin{array}{l}8,9,10,19,21,23,28,29,32,33,34,36,38,4 \\
0,43,45,51,53\end{array}$ & 27.69 \\
\hline Good (80-94) & $\begin{array}{l}1,4,5,11,14,15,17,18,21,23,30 \\
31,35,39,41,51,53,54,61,62\end{array}$ & 31 & $\begin{array}{l}13,14,15,22,24,26,27,31,35,37 \\
39,41,42,44,48,56,57,58,62,64,65\end{array}$ & 32.3 \\
\hline Excellent (95-100) & $6,24,50,55$ & 5 & $1,2,4,5,6,7,18,20,30,47,49,50,61$ & 20 \\
\hline \multicolumn{5}{|c|}{ (b) GWQI } \\
\hline Excellent $(<50)$ & 42 & 1.5 & $1,2,4,6,7,39,41,42,46,59,60,62,63$ & 20 \\
\hline
\end{tabular}




\begin{tabular}{|c|c|c|c|c|}
\hline $\begin{array}{l}\text { Good } \\
(50-100)\end{array}$ & $\begin{array}{l}2,4,5,6,7,8,9,10,11,12,13,14,1 \\
5,17,18,19,21,22,23,24,25,26 \\
27,30,31,32,33,36,37,38,39,40 \\
, 41,44,45,46,48,49,50,51,52,5 \\
5,56,58,63,65\end{array}$ & 70.7 & $\begin{array}{l}3,5,8,10,11,13,14,15,16,17,18,19,21,22 \\
, 23,24,25,26,27,28,29,30,31,32,33,34,3 \\
5,36,37,38,40,43,44,45,47,48,49,50,51, \\
52,53,54,55,56,57,58,61,64,65\end{array}$ & 75.4 \\
\hline Poor $(100-200)$ & $\begin{array}{l}1,3,16,20,28,29,34,35,43,47,5 \\
3,54,57,59,60,61,62,64\end{array}$ & 27.7 & $9,12,20$ & 4.6 \\
\hline $\begin{array}{l}\text { Very Poor (200- } \\
\text { 300) } \\
\text { Unfit (>300) }\end{array}$ & $\begin{array}{l}0 \\
0\end{array}$ & $\begin{array}{l}0 \\
0\end{array}$ & $\begin{array}{l}0 \\
0\end{array}$ & $\begin{array}{l}0 \\
0\end{array}$ \\
\hline
\end{tabular}

Table 4 Calculated Value of RMSE and MAPE

\begin{tabular}{ccccc}
\hline & CCMEWQI & POM & PRM & GWQI \\
& PRM & POM & POM \\
\hline NMSE & 4.34 & 2.42 & 6.35 & 5.24 \\
RMSE & 27.38 & 24.76 & 42.07 & 41.79 \\
MAPE & 0.357 & 0.295 & 0.418 & 0.531 \\
$\mathrm{R}^{2}$ & 0.97 & 0.95 & 0.95 & 0.94 \\
\hline
\end{tabular}

\subsection{Spatial distribution of heavy metals}

There are significant differences in the concentration level of heavy metals in the groundwater of the study area. An elevated concentration range of $\mathrm{Mn}(25.5$ to $1086 \mu \mathrm{g} / \mathrm{l})$ was observed in the study area, followed by Fe (64 to $801 \mu \mathrm{g} / \mathrm{l})$ and As (0 to $125.5 \mu \mathrm{g} / \mathrm{l}$ ), which exceeded the guideline value of WHO (2011). The spatial distribution pattern of all six selected elements viz. arsenic (As), Iron (Fe), Manganese (Mn), Nickel (Ni), Lead (Pb), and Copper $(\mathrm{Cu})$, is presented in Fig. 6 a-f. The level of As was observed to be dominated throughout the study area except for the eastern zone. The higher level of As in this region may be because of discharging the industrial effluent into the open ground, resulting in groundwater contamination by infiltration (Khalid et al. 2020). Additionally, the groundwater aquifers of this area are underlain mainly in the Chotanagpur consolidated granite-gneiss rocks of Archaean age comprised of quartzite and schist may be one of the sources for As due to the occurrence of chemical weathering (Trikery et al. 2016). However, only the eastern region of the study area falls under the safe zone concerning the As contamination (Fig. 6a).

The earth's crust naturally contains Iron (Fe) and Manganese (Mn), which may pose several issues to the groundwater if it exceeds the permissible limit (Wallace et al. 2012). The spatial distribution map revealed that Fe dominates the central, eastern, and some portions of western regions (Fig. 6 b). The distribution of Fe in the groundwater of this area may be attributed to the earth's crust and the geological formation of the area (Banks et al. 1997; Dang et al. 2002; Senapaty and Behera 2012). $\mathrm{Mn}$ is one of the essential elements that contribute to several significant physiological processes of the human body (Arauz et al. 2008). The high concentration of Mn was only distributed over the southeast part of the study area near Hatia, and the rest comes under the safe zone for drinking purposes (Fig. 6 c). The spatial distribution of $\mathrm{Ni}, \mathrm{Pb}$ and $\mathrm{Cu}$ indicated that all three elements mostly come under the safe zone for drinking purposes throughout the study area (Fig $6 \mathrm{~d}$-e-f). 

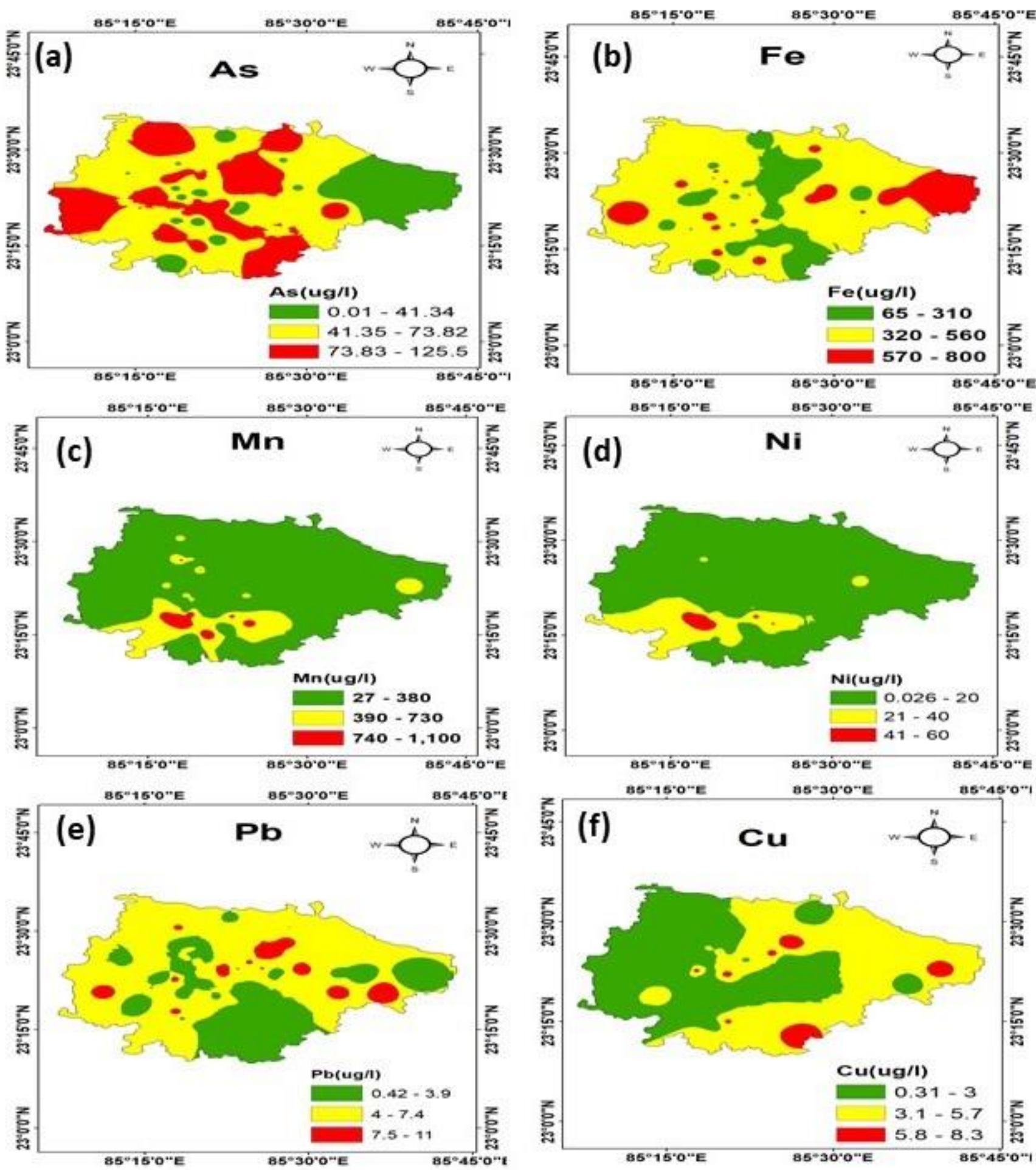

Fig. 6 a-f Spatial distribution Hevy metal (a) As (b) $\mathrm{Fe}$ (v) $\mathrm{Mn}$ (d) $\mathrm{Ni}$ (e) $\mathrm{Pb}$ (f) $\mathrm{Cu}$ 


\section{$294 \quad 3.5$ Human health risk assessment of heavy metals}

295 The health risk of heavy metals in groundwater via the oral route was investigated for all 65 locations. The value of HQ, which 296 expresses the effects of non-carcinogenic risk, was observed maximum for As followed by $\mathrm{Mn}>\mathrm{Pb}>\mathrm{Ni}>\mathrm{Fe}>\mathrm{Cu}$ for adults 297 and children (Fig. 7a-f). The HQ of each metal except As was observed less than unity, indicating no significant health risk on 298 humans from the intake of these metals. Moreover, the elevated HQ of As may be due to its high concentration range in the 299 water. The risk associated with oral ingestion depends on the individual body weight and consumed volume of water (Asare et 300 al. 2016). Moreover, the HI value of the study area range from 0.1 to 25.1 and 0.2 to 29.8 for adult and children, respectively. 301 Its value greater than unity indicates the non-carcinogenic risk, while $\leq 1$ is supposed to be safe (Asare et al. 2016). The spatial 302 distribution map of $\mathrm{HI}$ indicated that most of the studies area are at a non-carcinogenic risk of heavy metals that may possess 303 serious health issues (Duggal et al. 2017) (Fig. 8a-b). However, the only northern region that comes under the safe zone 304 concerning health risks. It was also noticed that the children are more porn to the non-carcinogenic risk of heavy metals vis 305 oral ingestion than adults. A similar observation was also reported by (Duggal et al. 2017) 

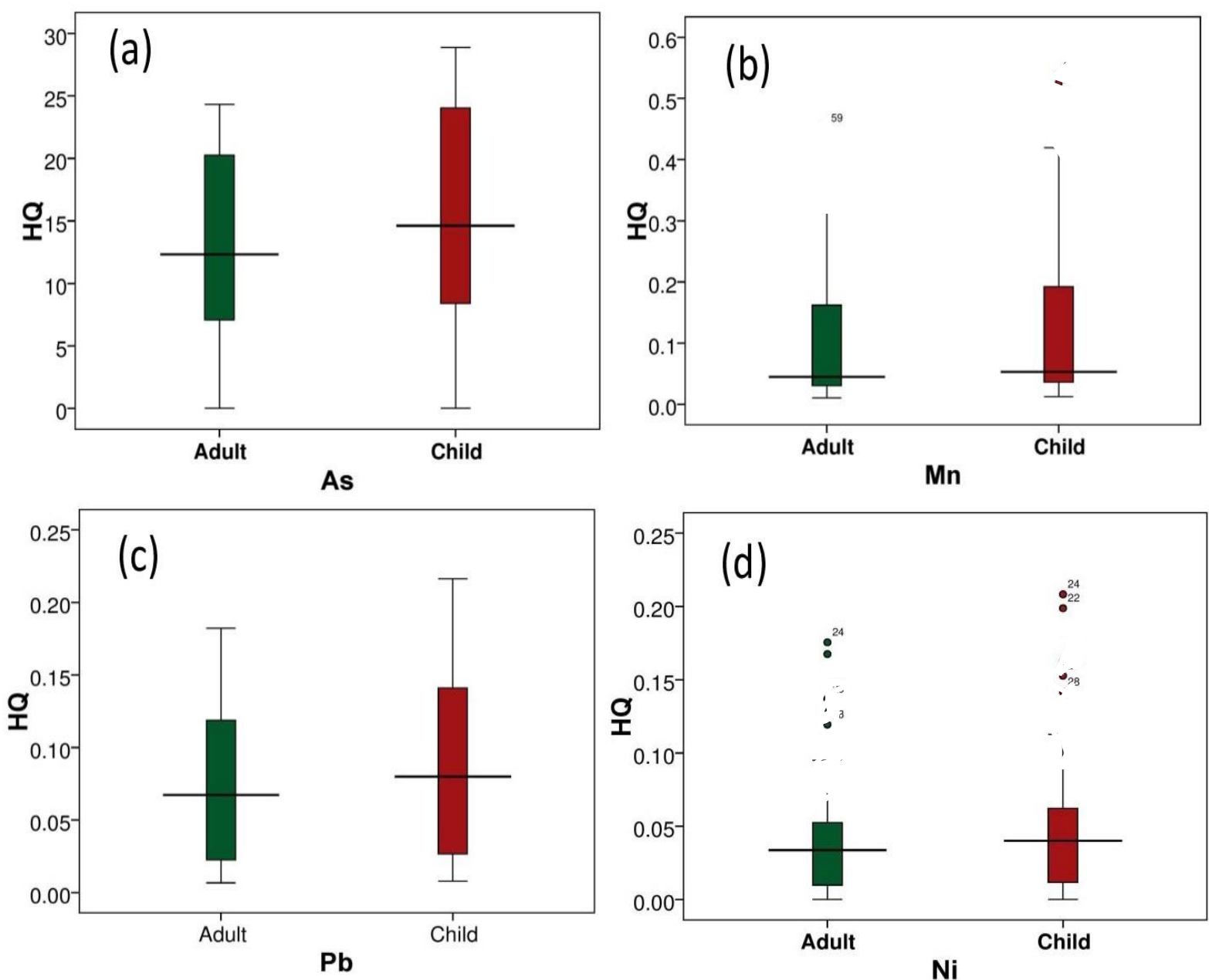

306
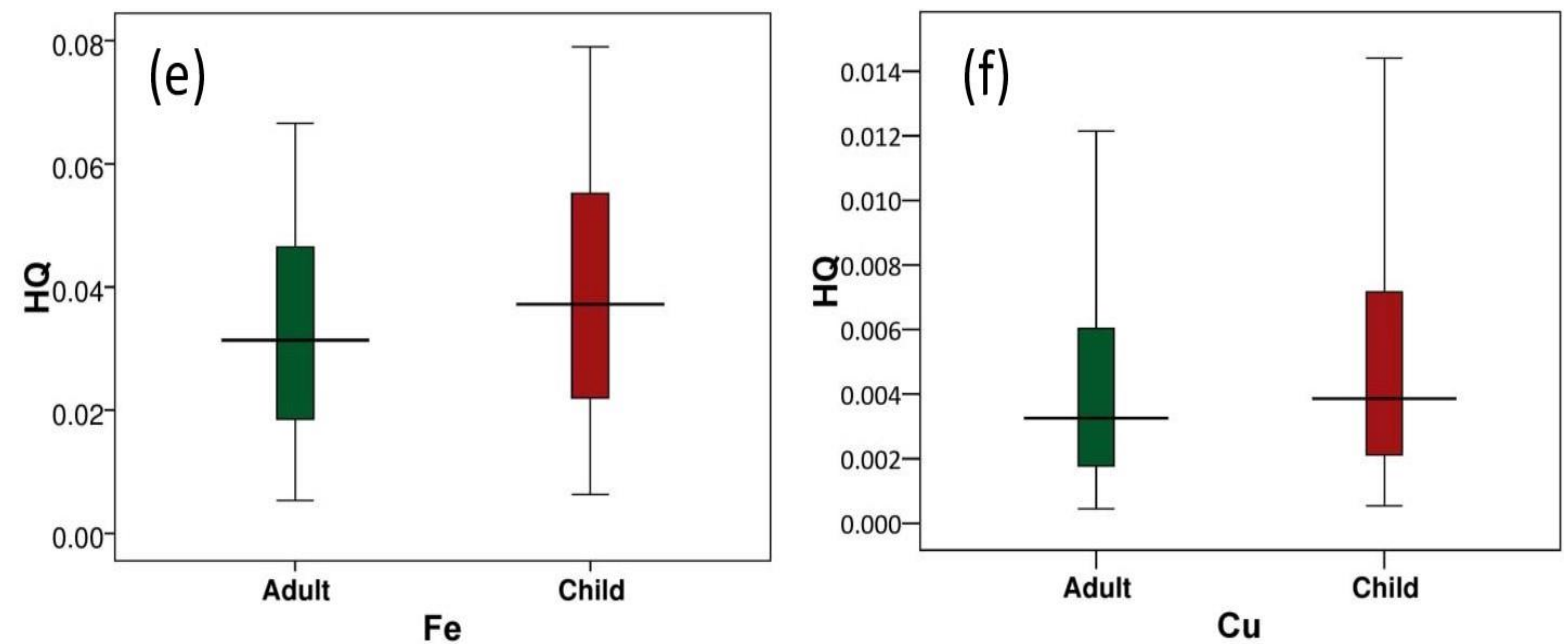

Fig. 7 Box plot diagram of Hazard Quient (HQ) of (a) Arsenic, (b) Manganese, (c) Lead, (d) Nickel, (e) Iron, 308 (f) Copper 

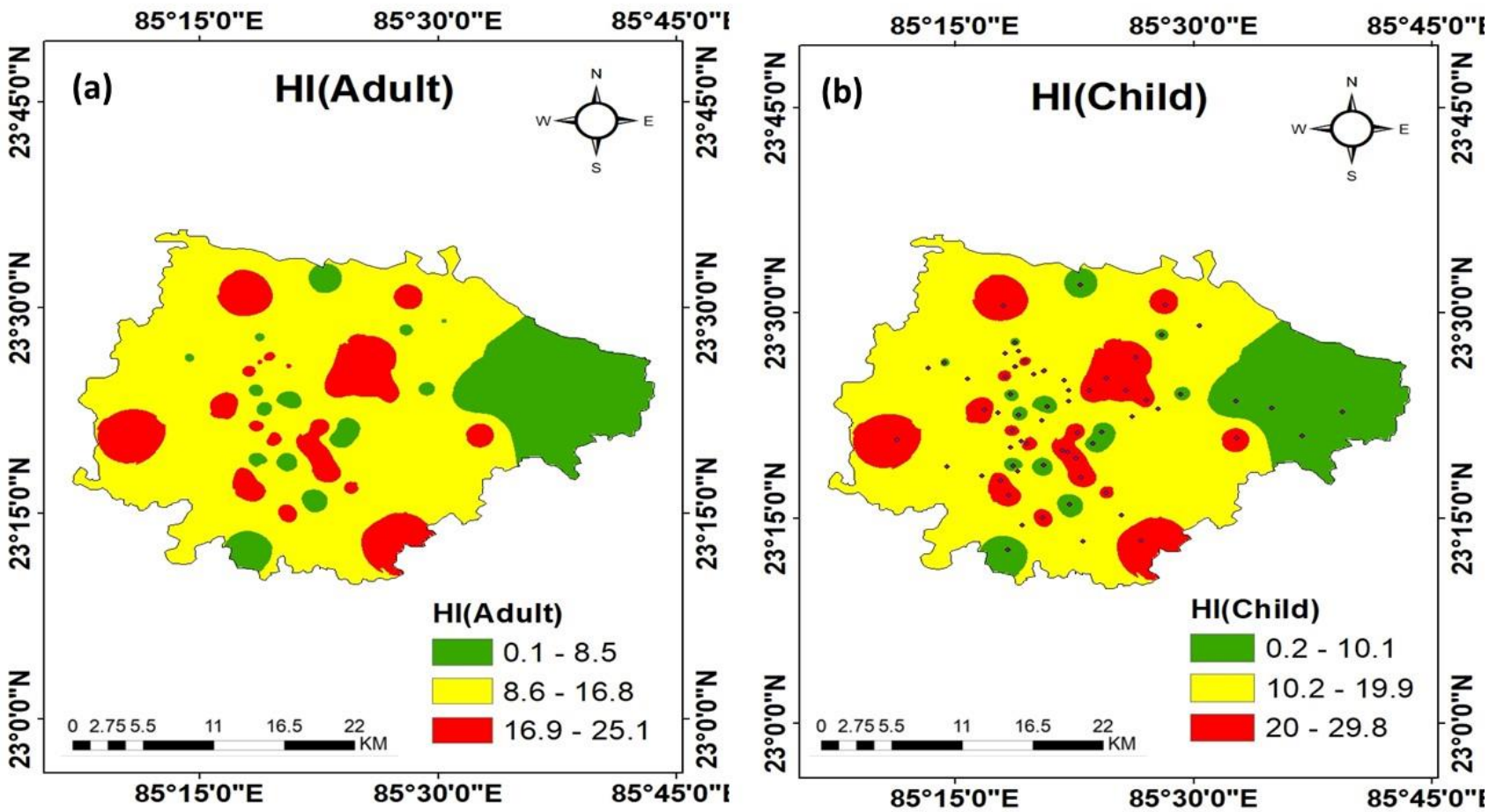

Fig. 8 Spatial distribution map of hazardous Index(HI) of (a) Adult, (b) child

4.0 Conclusions

The current research highlighted the need for adopting an effective WQI model for assessing the suitability of groundwater. Monitored heavy metals concentration is well compiled with the guideline of WHO, except Mn (25.5 to $1086 \mu \mathrm{g} / \mathrm{l}), \mathrm{Fe}(64$ to $801 \mu \mathrm{g} / \mathrm{l})$, and As (0 to $125.5 \mu \mathrm{g} / \mathrm{l})$. The spatial distribution map revealed the dominancy of arsenic throughout the study area except for the eastern region. Notable seasonal fluctuations of groundwater level (PRM -7.38mbgl to $10.5 \mathrm{mbgl}$, POM 4.3- $6.4 \mathrm{mbgl}$ ) were observed in the only central zone. Conclusive evidence of sensitivity analysis revealed that CCMEWQI $\left(R^{2} 0.97\right)$ performed better than GWQI $\left(R^{2}\right.$ 0.95 ) for assessing the quality index of groundwater. The calculated non-carcinogenic risks of heavy metals indicated that most of the study areas are at a non-carcinogenic risk, except the northern region. Continuous monitoring and treatment are essential to reduce health risks in the study area. 
332 Not applicable

333 Consent for publication

334 Not applicable

335 Availability of data and materials

336 Data collected and analyzed in this study are available from the corresponding author upon request.

337 Competing interests

338 The authors declare that they have no conflict of interest.

339 Funding

$340 \quad$ Not applicable

341 Authors' contributions

342 Shivam Saw (first): Methodology, Statistical analysis, Writing the original manuscript, Jaydev Kumar Mahato:

343 Conceptualization and modeling, Prasoon Kumar Singh: Supervision.

344 Acknowledgments

345 The authors are highly thankful to the Department of Environmental Science and Engineering, Indian Institute of 346 Technology (ISM), Dhanbad, for providing the necessary support and facilities for carrying out research work.

347 The first author(Shivam Saw) is grateful to MHRD, GoI, for providing PhD fellowship.

348 Authors' information (optional)

349 Not Applicable

350

351

352

353

354

355

356

357

358

359

360 


\section{References}

Adimalla N (2019) Controlling factors and mechanism of groundwater quality variation in semiarid region of South India: an approach of water quality index (WQI) and health risk assessment (HRA). Environmental Geochemistry and Health 1-28.

Aller L, Bennet T, Leher JH, Petty RJ, Hackett G (1987) DRASTIC: a standardized system for evaluating ground water pollution potential using hydro-geological settings Environmental Protection Agency (EPA) 600/2-87-035:622.

American Public Health Association (APHA) (2012) Standard methods for the examination of water and wastewater. 21st ed. American Public Health Association New York.

APHA (2012) Standard Method for the Examination of Water and Waste water twenty-second ed. Washington D.C.

Asare-Donkor NK, Boadu TA, Adimado AA (2016) Evaluation of groundwater and surface water quality and human risk assessment for trace metals in human settlements around the Bosomtwe Crater Lake in Ghana. SpringerPlus, 5(1), 1812.

Banks D, Younger PL, Arnesen R, Iversen ER, Banks SB (1997) Mine water chemistry the good the bad and the ugly. Environ Geol 32(3):157-174.

Bhargava DS (1983) Use of a water quality index for river classification and zoning of the Ganga River. Environ Pollut B6:51-67.

Bhutiani R, Kulkarni DB, Khanna DR Gautam A (2016) Water quality pollution source apportionment and health risk assessment of heavy metals in groundwater of an industrial area in North India. Exposure and Health 8(1):3-18.

BIS (2012) Indian standards specification for drinking water BIS: 10500 Bordalo AA, Teixeira R, Wiebe WJ (2006) A water quality index applied to an international shared river basin the case of the Douro River. Environ Manage 38(6):910-920.

Brown RM, Mclelland NI, Deininger RA, Tozer RG (1970) A water quality index-Do we dare? Water Sew Works. 117(10):339-343.

Canadian Council of Ministers of Environment (2001) Canadian water quality guidelines for the protection of aquatic life CCME Water Quality Index 1.0 Technical Report In Canadian Environmental Quality Guidelines (2001) Canadian Council of Ministers of the Environment Winnipeg Canada. 
Canadian Council of Ministers of the Environment (CCME) (2001) Canadian Water Quality Index 1.0 Technical report and user's manual. Canadian Environmental Quality Guidelines Water Quality Index Technical Subcommittee. Gatineau QC Canada.

Chaurasia AK, Pande HK, Tiwari SK, Pandey P, Ram A (2021) Groundwater vulnerability assessment using water quality index (WQI) under geographic information system (GIS) framework in parts of Uttar Pradesh India. Sustainable Water Resources Management 7(3):1-15.

Duggal V, Rani A, Mehra R, Balaram V (2017) Risk assessment of metals from groundwater in northeast Rajasthan. Journal of the Geological Society of India 90(1):77-84.

Egbueri JC (2020) Groundwater quality assessment using pollution index of Groundwater (PIG), ecological risk index (ERI) and hierarchical cluster analysis (HCA) a case study. Groundwater for Sustainable Development 10100292.

Gopal K, Surjeet S, Kumar CP, Suman G, Ghosh NC (2016) Assessment of water quality index (WQI) of groundwater in Rajkot district Gujarat India. Journal of Earth Science \& Climatic Change 7(3)

Gopinath G, Seralathan P (2006) Chemistry of Groundwater in the laterite formation of Muvatterpuzha river basin Kerala J Geol Soc India 68:705-714.

GSI (2001) Geological Survey of India, home (gsi.gov.in) GSI Report.

Horton RK (1965) An index number system for rating water quality. J Water Pollution Control Fed 37(3):300306.

ICMR (Indian Council of Medical Research) (2009) Nutrient requirements and recommended dietary allowances for Indians. A report of the expert group of the ICMR, Hyderabad, India p 334.

Khalid S, Shahid M, Shah AH, Saeed F, Ali M, Qaisrani SA, Dumat C (2020) Heavy metal contamination and exposure risk assessment via drinking groundwater in Vehari Pakistan. Environmental Science and Pollution Research 27(32):39852-39864.

Khan A, Paterson R, Khan H (2003) Modification and Application of the CCME WQI for the Communication of Drinking Water Quality Data in Newfoundland and Labrador Presented at $38^{\text {th }}$ Central Symposium on Water Quality Research, Canadian Association on Water Quality (February 10-11, 2003) 867 Lakeshore Road Burlington, ON, Canada.

Kumar A, Krishna AP (2021) Groundwater quality assessment using geospatial technique based water quality index (WQI) approach in a coal mining region of India. Arabian Journal of Geosciences 14(12):1-26. 
Latha PS, Rao KN (2010) Assessment and Spatial Distribution of Quality of Groundwater in ZoneII and III Greater Visakhapatnam India Using Water Quality Index (WQI) and GIS. International Journal of environmental sciences1(2):198-212.

Magesh NS, Krishnakumar S, Chandrasekar N, Soundranayagam JP (2013) Groundwater quality assessment using WQI and GIS techniques Dindigul district Tamil Nadu India. Arabian Journal of Geosciences 6(11):4179-4189.

Mahato JK, Gupta SK (2021) Exceptional adsorption of different spectral indices of natural organic matter (NOM) by using cerium oxide nanoparticles (CONPs). Environmental Science and Pollution Research 1-10.

Mamatha P, Rao SM (2010) Geochemistry of fluoride rich groundwater in Kolar and Tumkur Districts of Karnataka. Environmental Earth Sciences 61(1):131-142.

Mazhar SN, Ahmad S (2020) Assessment of water quality pollution indices and distribution of heavy metals in drinking water in Ramganga aquifer Bareilly District Uttar Pradesh India. Groundwater for Sustainable Development 10:100-304.

Mohebbi MR, Saeedi R, Montazeri A, Vaghefi, KA, Labbafi S, Oktaie S, Mohagheghian A (2013) Assessment of water quality in groundwater resources of Iran using a modified drinking water quality index (DWQI). Ecological indicators 30:28-34.

Negrel P, Roy S (1998) Rain chemistry in the Massif Central (France) A strontium isotopic and major elements study. App Geochem 13:941-952.

Nickson RT, McArthur J M, Shrestha B, Kyaw-Myint T O, Lowry D (2005) Arsenic and other drinking water quality issues Muzaffargarh District Pakistan. Applied geochemistry 20(1):55-68

Panaskar DB, Wagh VM, Muley AA, Mukate SV, Pawar RS, Aamalawar ML (2016) Evaluating groundwater suitability for the domestic, irrigation, and industrial purposes in Nanded Tehsil, Maharashtra, India, using GIS and statistics. Arabian J Geosci 9(13):615.

Rafique T, Naseem S, Bhanger MI, Usmani, TH (2008) Fluoride ion contamination in the groundwater of Mithi sub-district the Thar Desert Pakistan. Environmental Geology 56(2):317-326.

Raghunath HM (1982) Groundwater Wiley, New Delhi, p 456.

Rajankar PN, Gulhane SR, Tambekar DH, Ramteke DS, Wate SR (2009) Water quality assessment of groundwater resources in Nagpur Region (India) based on WQI. E-Journal of Chemistry 6(3):905-908.

Ramakrishnaiah CR, Sadashivaiah C, Ranganna G (2009) Assessment of water quality index for the groundwater in Tumkur Taluk Karnataka State India. E-Journal of chemistry 6(2):523-530. 
Rao GT, Rao VG, Rao YS, Ramesh G (2013) Study of hydrogeochemical processes of the Groundwater in Ghatprabha river sub-basin, Bagalkot District Karnataka India. Arabian Journal of Geosciences 6(7): 2447-2459.

Rocchini R, Swain LG (1995) The British Columbia Water Quality Index. Victoria, BC, Canada: Water Quality Branch, Environmental Protection Department, British Columbia Ministry of Environment, Land and Parks,(13 pp).

Senapaty A, Behera P (2012) Concentration and distribution of trace elements in different coal seams of the Talcher Coalfield Odisha. Int J Earth Sci Eng 5(1):80-7.

Srinivasamoorthy K, Chidambaram M, Prasanna MV, Anandhan P (2007) Control of rock weathering on the chemical composition of Groundwater in Salem District Tamilnadu India. International Journal of Physical Sciences 19(3):367-378.

Steinhart CE, Schierow LJ, Chesters G (1981) A review of water quality and related indices Great Lakes Environmental Planning Study Contribution No. 38. Water Resources Centre University of Wisconsin Madison Wisconsin 53706.

Tiwari AK, Mahato MK, Singh PK (2013), Quality assessment and suitability for irrigation uses of surface water of Pratapgarh district Indian. J Environmental Protection 33(5): 370-378.

Tiwari AK, Singh AK (2014). Hydrogeochemical investigation and groundwater quality assessment of Pratapgarh district, Uttar Pradesh. J Geol Soc India 83(3):329-343.

US EPA (2011) Edition of the Drinking Water Standards and Health Advisories EPA 820-R-11-002 Office of Water, U.S. Environmental Protection Agency Washington, DC.

Venkatramanan S, Chung SY, Ramkumar T, Rajesh R, \& Gnanachandrasamy G (2016) Assessment of groundwater quality using GIS and CCME WQI techniques: a case study of Thiruthuraipoondi city in Cauvery deltaic region Tamil Nadu India. Desalination and Water Treatment 57(26):12058-12073.

Wagh VM, Panaskar DB, Varade AM, Mukate SV, Gaikwad SK, Pawar RS, Muley AA, Aamalawar ML (2016) Major ion chemistry and quality assessment of the groundwater resources of Nanded tehsil a part of southeast Deccan Volcanic Province, Maharashtra India. Environ Earth Sci 75(21):1418.

Wagh VM, Panaskar DB, Mukate SV, Gaikwad SK, Muley AA, Varade AM (2018) Health risk assessment of heavy metal contamination in groundwater of Kadava River Basin, Nashik India. Modeling Earth Systems and Environment 4(3):969-980. 
479 Wagh VM, Panaskar DB, Muley AA, Mukate SV (2017) Groundwater suitability evaluation by CCME WQI model for Kadava river basin Nashik Maharashtra India. Modeling Earth Systems and Environment 3(2):557-565.

482 Wallace SH, Shaw S, Morris K, Small JS, Fuller AJ, Burke IT (2012) Effect of groundwater pH and ionic strength on strontium sorption in aquifer sediments: Implications for $90 \mathrm{Sr}$ mobility at contaminated nuclear sites. Applied Geochemistry 27(8):1482-1491.

485

WHO (2011) Guidelines for Drinking-water Quality Fourth ed, Recommendations vol 1World Health Organization, Geneva, Switzerland.

World Bank (2010) India Water Resources Management Sector Review: Groundwater Regulation and Management Report World Development Sources, WDS 1998-3 (Washington, DC: World Bank). relational method. Journal of Hydrology 543:316-323. 